\title{
EFEKTIVITAS MODEL PEMBELAJARAN MISSOURI MATHEMATICS PROJECT (MMP) TERHADAP KEMAMPUAN KOMUNIKASI MATEMATIS SISWA SMP
}

\author{
Amanatul Ummah, Riska Novia Sari* \\ Program Studi Pendidikan Matematika Fakultas Keguruan dan Ilmu Pendidikan, \\ Universitas Riau Kepulauan, Batam, Indonesia \\ Email: "riskanovia30@gmail.com
}

\begin{abstract}
Abstrak. Penelitian ini bertujuan untuk mengetahui: (1) Efektivitas model pembelajaran MMP terhadap kemampuan komunikasi matematis, (2) Efektivitas model pembelajaran konvensional terhadap kemampuan komunikasi matematis, dan (3) Perbedaan keefektifan model pembelajaran MMP dengan model pembelajaran konvensional terhadap kemampuan komunikasi matematis. Jenis penelitian ini adalah penelitian kuasi eksperimen dengan desain penelitian The Non equivalent Control Group Design. Populasi penelitian terdiri dari seluruh siswa kelas VIII SMP IT Nurul Muhajirin Batam Tahun Ajaran 2016/2017 yang terbagi dalam empat kelas dengan jumlah 106 orang siswa. Teknik pengambilan sampel yang digunakan adalah purposive sampling, sehingga dipilih dua kelas sebagai sampel dengan jumlah 53 orang siswa. Analisis data yang digunakan adalah uji t. Hasil penelitian ini menunjukkan: (1) Model pembelajaran MMP efektif ditinjau dari kemampuan komunikasi matematis, (2) Model pembelajaran konvensional tidak efektif ditinjau dari kemampuan komunikasi matematis, (3) Terdapat perbedaan keefektifan model pembelajaran MMP dengan pembelajaran konvensional ditinjau dari kemampuan komunikasi matematis.
\end{abstract}

Kata Kunci: Missouri Mathematics Project, Model Pembelajaran Konvensional, Kemampuan Komunikasi Matematis

\begin{abstract}
This research aims to find out: 1) effectiviness of the learning model Missouri Mathematics Project (MMP) to the ability of mathematical communication, 2) effectiviness of the learning model conventional to the ability of mathematical communication, 3) the difference effectiviness of the learning model MMP and conventional to the ability of mathematical communication student grade VIII of SMP IT Nurul Muhajirin Batam for 2016/2017 academic years. This research was quasi experimental research with the non equivalent control group design.The population in this research is all the student grade VIII SMPIT Nurul Muhajirin in Batam 2016/2017 academic years which is divided in four classes with 106 students. The technique of collecting sample used purposive sampling with 53 students. Data analisys used T test. The result of this research show that, 1) learning model MMP effective reviewed by the ability of mathematical comunication, 2) Conventional learning model is not effective reviewed by the ability of mathematical communication, 3) There is a difference in the effectiviness of the learning model MMP with conventional model reviewed by the ability of mathematical communication.
\end{abstract}

Keywords: Missouri Mathematics Project, Learning Model Conventional, Ability of mathematical communication.

\section{Pendahuluan}

Pendidikan merupakan suatu proses untuk meningkatkan kualitas Sumber Daya Manusia (SDM) dalam usaha membimbing anak menjadi dewasa agar cukup cakap menyelenggarakan tugas hidupnya atas tanggungjawabnya sendiri. Dengan tujuan untuk menuntun mereka sebagai manusia dan sebagai anggota masyarakat yang bertanggung jawab agar dapat mencapai potensi semaksimal mungkin, baik potensi secara fisik, emosi, sosial, moral, pengetahuan dan keterampilan. Membahas mengenai pendidikan guru merupakan 
komponen yang sangat menentukan dalam penerapan proses pembelajaran di dalam kelas sebagai unsur mikro dari suatu keberhasilan pendidikan.

Salah satu upaya pendidikan menghasilkan Sumber Daya Manusia (SDM) yang berkualitas adalah melalui pendidikan matematika sehingga siswa memiliki kemampuan memperoleh, memanfaatkan, dan mengelola informasi pada keadaan yang selalu berubah, tidak pasti, dan kompetitif. Matematika juga merupakan ilmu yang mendasari perkembangan teknologi modern, mempunyai peran penting dalam perkembangan ilmu dan kemampuan daya pikir manusia. Peraturan Menteri Pendidikan Nasional (Permendiknas) nomor 20 tahun 2006 menjelaskan bahwa matematika adalah salah satu pelajaran pokok dengan tujuan agar siswa mempunyai kemampuan antara lain kemampuan pemahaman konsep matematis, menggunakan penalaran, memecahkan masalah, mengkomunikasikan gagasan dan memiliki sikap menghargai kegunaan matematika dalam kehidupan, memiliki rasa ingin tahu dan minat serta sikap ulet dan percaya diri dalam pemecahan masalah.

Sejalan dengan tujuan tersebut maka dapat disimpulkan kemampuan komunikasi matematis merupakan aspek penting dalam pembelajaran matematika. Kemampuan komunikasi matematis yaitu kemampuan siswa menyampaikan gagasan/ide matematis atau konsep matematika, baik secara lisan maupun tulisan kepada orang lain, serta kemampuan untuk menggunakan bahasa matematika dan mengekspresikan ide-ide matematika secara benar ke dalam bentuk gambar maupun simbol atau istilah-istilah tertentu (Ramellan P, Musdi, 2012);(Ramdani, 2012);(Lestari \& Yudhanegara, 2015);(Giawa, I.R.F, Hutagaol, K \& Saragih, 2013).

Namun, kenyataan di lapangan menunjukkan bahwa kemampuan matematis siswa masih tergolong rendah. Hal ini berdasarkan observasi awal yang dilakukan dengan mengujikan dua buah soal kemampuan komunikasi matematis kepada 26 orang siswa SMP IT Nurul Muhajirin pada materi Sistem Persamaan Linear Dua Variabel (SPLDV). Soal yang diberikan meminta siswa membuat model matematika dari permasalahan yang diberikan kemudian menyelesaikan model matematika tersebut untuk menentukan nilai dari masingmasing variabelnya. Berikut salah satu contoh soal yang diberikan:

Perhatikan tabel berikut

\begin{tabular}{|l|l|}
\hline \multicolumn{1}{|c|}{ Jumlah } & \multicolumn{1}{c|}{ Harga } \\
\hline $\begin{array}{l}2 \text { celana } \\
3 \text { baju }\end{array}$ & Rp. 85.000 \\
\hline $\begin{array}{l}3 \text { celana } \\
1 \text { baju }\end{array}$ & Rp. 75.000 \\
\hline
\end{tabular}

Dari tabel di atas buatlah persamaan matematika yang menghubungkan antara harga celana dan harga baju. Tentukanlah harga sebuah celana dan sebuah baju? Jelaskan jawabanmu!

Gambar 1. Soal Kemampuan Komunikasi Matematis

Hasil jawaban siswa di koreksi berdasarkan rubrik penilaian kemampuan komunikasi matematis. Untuk soal di atas jumlah siswa yang tidak dapat menyelesaikan soal yang diberikan sebanyak 13 siswa dengan persentase 50\%. Berikut contoh jawaban yang diberikan siswa: 


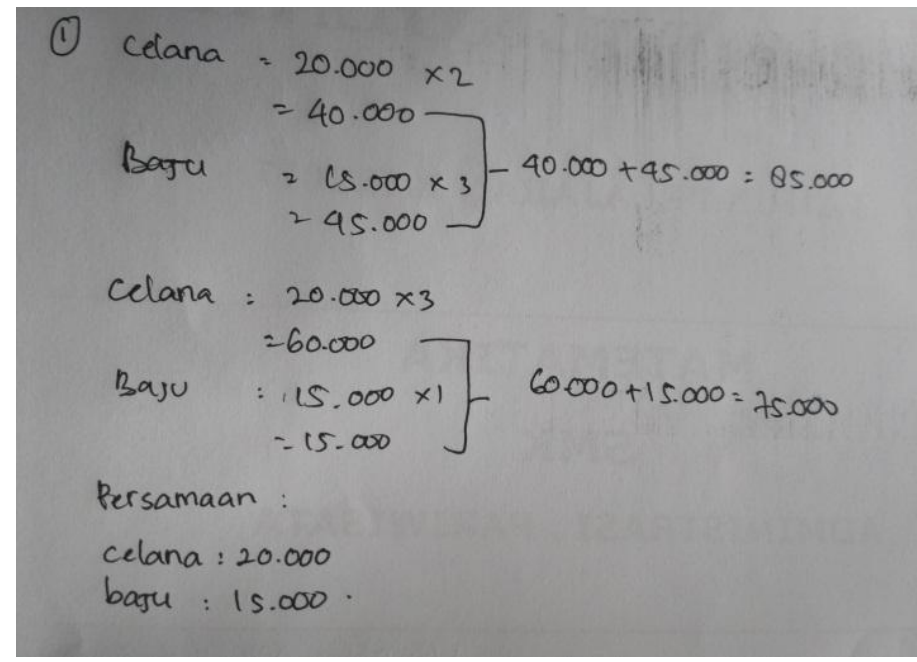

Gambar 2. Hasil Jawaban Siswa 1

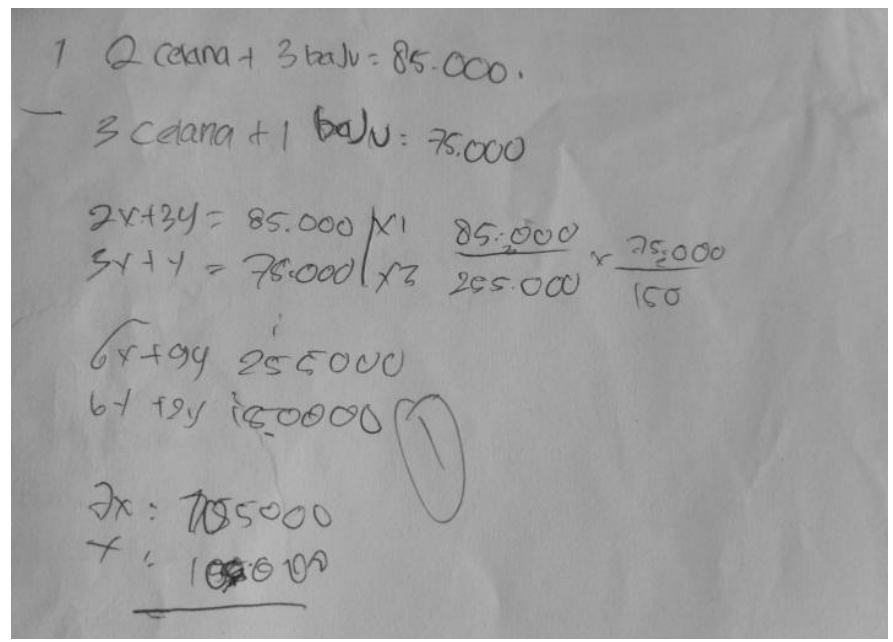

Gambar 3. Hasil Jawaban Siswa 2

Hasil jawaban siswa 1 di atas terlihat siswa belum bisa membuat model matematika dari permasalahan yang diberikan. Siswa membuat perkiraan harga dari masing-masing celana dan baju dan menguji apakah perkiraan tersebut benar dengan cara mengalikan dengan dengan banyaknya baju dan celana yang diketahui. Jawaban akhir siswa tersebut sudah benar namun proses untuk mendapatkan hasilnya yang masih keliru. Berbeda dengan siswa yang ke 2, siswa tersebut sudah bisa membuat model matematika dari permasalahan yang diberikan, namun masih keliru dalam menyelesaikan model matematika tersebut. Berdasarkan analisis jawaban siswa keseluruhan, masih banyak siswa yang belum dapat membuat model matematika, menyelesaikan SPLDV, baik penyelesaian dalam bentuk eliminasi dan subtitusi, serta belum bisa menyimpulkan hasil penyelesaian matematika yang telah dikerjakan.

Kemampuan komunikasi matematis dapat dibangun melalui proses latihan dan pembiasaan yang dilakukan secara berkelanjutan. Untuk mewujudkan hal itu, guru harus kreatif mengembangkan atau menggunakan strategi atau model pembelajaran yang dapat meningkatkan kemampuan komunikasi matematis siswa. Salah satu alternatif model 
pembelajaran yang diduga dapat meningkatkan komunikasi matematis siswa adalah model pembelajaran Missouri Mathematics Project (MMP). (Ansori, Hidayah \& Aulia, 2015) menyatakan bahwa model pembelajaran MMP merupakan suatu program yang didesain untuk membantu guru dalam hal efektivitas penggunaan latihan-latihan agar siswa mencapai peningkatan yang luar biasa. Melalui efektivitas penggunaan latihan-latihan siswa terbiasa menyelesaikan permasalahan-permasalahan matematika. Tujuan model pembelajaran MMP adalah menekankan pada gagasan-gagasan siswa untuk mengambil suatu keputusan dalam menyelesaikan persoalan matematika.

Penerapan model pembelajaran MMP ini diharapkan dapat meningkatkan kemampuan komunikasi matematis siswa, hal ini sejalan dengan hasil penelitian (Noviyanti, S., Kartono, 2014) dan (Rahmi \& Rahmi, 2015) bahwa model pembelajaran MMP berpengaruh positif dan efektif terhadap kemampuan komunikasi matematis siswa. Adapun langkah-langkah dalam menerapkan model pembelajaran MMP adalah sebagai berikut: (1) Guru meninjau ulang materi yang lalu yang terkait dengan materi baru serta menjelaskan tujuan pembelajaran yang akan dicapai, (2) Guru menjelaskan materi dengan menyajikan ide baru serta memberikan beberapa contoh konkret yang bersifat diskusi interaktif, (3) Guru memberikan latihan berupa lembar proyek/LKS yang dapat dikerjakan kelompok, (4) Guru membimbing siswa dalam mengerjakan latihan yang diberikan, (5) Guru memberikan latihan mandiri kepada siswa untuk mengukur pemahaman siswa dalam menyelesaikan permasalahan matematika, (6) Guru dan siswa menyimpulkan hasil pembelajaran yang telah dibahas.

\section{Metode Penelitian}

Penelitian ini merupakan penelitian kuasi eksperimen dimana variabel penelitian tidak dapat mengontrol variabel luar yang mempengaruhi penelitian. Penelitian ini menggunakan dua kelompok sampel yaitu kelompok eksperimen dengan menggunakan model pembelajaran MMP dan kelompok kontrol yang meggunakan model pembelajaran konvensional. Populasi pada penelitian ini adalah seluruh siswa kelas VIII SMP IT Nurul Muhajirin. Pengambilan sampel dilakukan dengan teknik purposive sampling. Adapun yang menjadi sampel dalam penelitian ini yaitu siswa kelas VIII A dan siswa kelas VIII B. Variabel yang digunakan dalam penelitian ini terbagi dua yaitu variabel bebas dengan model MMP dan model konvensional, sedangkan variabel terikat yaitu kemampuan komunikasi matematis. Instrumen yang digunakan adalah tes kemampuan komunikasi matematis dalam bentuk 7 buah soal tes uraian. Tes kemampuan komunikasi matematis dibuat berdasarkan indikator kemampuan komunikasi matematis yaitu: 1) menghubungkan benda nyata, gambar, dan diagram ke dalam ide matematika, 2) menjelaskan ide, situasi, dan relasi matematika secara tulisan dengan benda nyata, gambar, grafik dan aljabar.

Analisis instrumen meliputi uji validitas, uji reliabilitas, tingkat kesukaran, dan daya pembeda. Untuk uji validitas menggunakan validitas konstruk dengan rumus korelasi product moment diperoleh koefisien product moment dengan $0,584 \leq r_{\text {hitung }} \leq 0,832$ untuk setiap soal dengan $r_{\text {tabel }}=0,374$. Sehingga seluruh soal dinyatakan valid. Untuk uji reliabilitas tes menggunakan rumus Cronbach Alpha dengan hasil yang diperoleh yaitu 0,90>0,6 sehingga soal dinyatakan reliabel. Selanjutnya, dari 7 soal yang diujikan diperoleh 5 soal dengan kriteria sedang dan 2 soal dengan kriteria mudah. Perhitungan daya beda menghasilkan 4 soal 
dengan daya beda cukup dan 3 soal dengan daya beda baik. 7 soal tersebut digunakan dalam penelitian dan diberikan di akhir pertemuan (pos-test).

Teknik analisis data yang digunakan untuk menguji hipotesis penelitian adalah Uji-t satu sampel dan Uji-t dua sampel. Sebelum dilakukan uji hipotesis terlebih dahulu akan dilakukan uji prasyarat diantaranya yaitu uji normalitas dan uji homogenitas.

\section{Hasil Penelitian Dan Pembahasan}

Setelah diberikan perlakuan pada kelas eksperimen dengan model pembelajaran MMP dan kelas kontrol dengan model pembelajaran konvensional, kedua kelas diberikan post-test dengan hasil sebagai berikut:

Tabel 1. Deskripsi Data Hasil Post-test

\begin{tabular}{ccccc}
\hline No & Kelompok & Mean & Standar Deviasi & Sampel \\
\hline 1 & Eksperimen (MMP) & 79,63 & 13,93 & 27 \\
2 & Kontrol (Konvensional) & 71,02 & 11,97 & 26 \\
\hline
\end{tabular}

Berdasarkan Tabel 1 di atas diperoleh rata-rata untuk kelas eksperimen yaitu 79,63 dan rata-rata kelas kontrol yaitu 71,02. Terlihat bahwa rata-rata kelas eksperimen lebih tinggi daripada kelas kontrol. Selanjutnya rata-rata kelas eksperimen sudah melewati Kriteria Ketuntasan Minimal (KKM) yang ditetapkan sekolah yaitu 75 dan kelas kontrol masih di bawah KKM. Sebelum data dianalisis menggunakan uji-t, terlebih dahulu akan dilakukan uji normalitas data dan uji homogenitas data. Uji normalitas dalam penelitian ini menggunakan rumus Kolmogorov-Smirnov dan uji homogenitas menggunakan uji F. Berdasarkan perhitungan diperoleh hasil sebagai berikut:

Tabel 2. Hasil Perhitungan Uji Normalitas

\begin{tabular}{ccccc}
\hline Posttest & $\boldsymbol{D}_{\text {hitung }}$ & $\boldsymbol{D}_{\text {tabel }}$ & Keputusan & Keterangan \\
\hline Eksperimen & 0,17 & 0,26 & $\mathrm{H}_{0}$ diterima & Normal \\
Kontrol & 0,08 & 0,26 & $\mathrm{H}_{0}$ diterima & Normal \\
\hline
\end{tabular}

Tabel 3. Hasil Perhitungan Uji Homogenitas

\begin{tabular}{ccccc}
\hline Kelas & $\boldsymbol{F}_{\text {hitung }}$ & $\boldsymbol{F}_{\text {tabel }}$ & Keputusan & Keterangan \\
\hline $\begin{array}{c}\text { Eksperimen dan } \\
\text { control }\end{array}$ & 1,36 & 1,93 & $\mathrm{H}_{0}$ diterima & Homogen \\
\hline
\end{tabular}

Berdasarkan hasil perhitungan uji normalitas, dapat disimpulkan bahwa data post-test kelas eksperimen dan kelas kontrol berasal dari populasi yang berdistribusi normal. Untuk hasil perhitungan uji homogenitas, diperoleh nilai $F_{\text {hitung }}<F_{\text {tabel }}$ yaitu $1,36<1,93$. Maka dapat disimpulkan bahwa kedua data post-test memiliki varians yang homogen. Karena kedua kelas sudah memiliki data yang normal dan homogen maka dilanjutkan dengan analisis data. Berikut hasil pengujian hipotesis 1 menggunakan uji t satu sampel: 
Tabel 4. Hasil Perhitungan Hipotesis 1

\begin{tabular}{cccc}
\hline Kelas & $\boldsymbol{T}_{\text {hitung }}$ & $\boldsymbol{T}_{\text {tabel }}$ & Keterangan \\
\hline Eksperimen & 1,73 & 1,70 & Ha diterima \\
\hline
\end{tabular}

Dari hasil pengujian hipotesis 1 diperoleh $t_{\text {hitung }}>t_{\text {tabel }}$ yaitu 1,73 $>1,70$. Maka dapat disimpulkan bahwa model pembelajaran MMP efektif terhadap kemampuan komunikasi matematis siswa kelas VIII SMP IT Nurul Muhajirin. Selanjutnya, hasil pengujian hipotesis 2 sebagai berikut:

Tabel 5. Hasil Perhitungan Hipotesis 2

\begin{tabular}{cccc}
\hline Kelas & $\boldsymbol{T}_{\text {hitung }}$ & $\boldsymbol{T}_{\text {tabel }}$ & Keterangan \\
\hline Kontrol & $-1,69$ & 1,70 & $\mathrm{H}_{0}$ diterima \\
\hline
\end{tabular}

Selanjutnya hasil pengujian hipotesis 2 diperoleh $t_{\text {hitung }}<t_{\text {tabel }}$ yaitu $-1,69<1,70$. Sehingga disimpulkan bahwa model pembelajaran konvensional tidak efektif terhadap kemampuan komunikasi matematis pada materi Bangun Ruang Sisi Datar siswa kelas VIII SMP IT Nurul Muhajirin. Untuk melihat apakah terdapat perbedaan keefektifan kedua kelas dilakukan uji hipotesis ketiga dengan menggunakan uji t dua sampel dengan hasil sebagai berikut:

Tabel 6. Hasil Perhitungan Hipotesis 3

\begin{tabular}{ccccc}
\hline$\overline{\boldsymbol{X}}_{\mathbf{1}}$ & $\overline{\boldsymbol{X}}_{\mathbf{2}}$ & $\boldsymbol{T}_{\text {hitung }}$ & $\boldsymbol{T}_{\text {tabel }}$ & Keterangan \\
\hline 79,63 & 71,02 & 2,41 & 1,67 & $\mathrm{H}_{\mathrm{a}}$ diterima \\
\hline
\end{tabular}

Berdasarkan hasil pengujian hipotesis 3 diperoleh $t_{\text {hitung }}>t_{\text {tabel }}$ yaitu 2,41 $>$ 1,67. Maka dapat disimpulkan bahwa terdapat perbedaan keefektifan model pembelajaran MMP dengan model pembelajaran konvensional terhadap dari kemampuan komunikasi matematis siswa kelas VIII SMP IT Nurul Muhajirin Batam Tahun Ajaran 2016/2017.

Hasil penelitian ini menunjukkan bahwa terdapat perbedaan keefektifan antara model pembelajaran MMP dan pembelajaran konvensional terhadap kemampuan komunikasi matematis pada materi bangun ruang sisi datar siswa kelas VIII SMP IT Nurul Muhajirin. Ditinjau dari rata-rata kelas, model pembelajaran MMP lebih baik daripada pembelajaran konvensional. Pada saat pelaksanaan penelitian dengan model pembelajaran MMP siswa terlihat lebih aktif dan bersemangat, hal ini dikarenakan di awal pembelajaran guru menyampaikan materi menggunakan alat peraga berupa kerangka balok dan kubus, dan guru melibatkan siswa secara aktif untuk mempraktekkan media tersebut. Selanjutnya pada tahap diskusi kelompok menyelesaikan tugas proyek yang diberikan oleh guru, terlihat siswa antusias. Setelah mengerjakan tugas proyek, siswa diberikan latihan mandiri oleh guru untuk melihat pemahaman mereka terhadap materi yang telah diberikan. Soal-soal latihan mandiri yang diberikan selama penelitian mencakup soal-soal dengan indikator kemampuan komunikasi matematis. Sedangkan pada kelas kontrol dengan pembelajaran konvensional guru menyampaikan materi pembelajaran seperti biasa dan juga menggunakan alat peraga. 
Setelah menyampaikan materi guru memberikan latihan-latihan soal yang berisi soal-soal dengan indikator kemampuan komunikasi matematis. Selama pembelajaran guru juga meminta siswa untuk bertanya apabila terdapat hal yang belum dipahami, tetapi hanya beberapa orang siswa yang bertanya dan yang lainnya memilih untuk diam. Untuk mengatasi hal tersebut guru memberikan reward terhadap siswa yang bertanya dan dapat menjawab pertanyaan guru yaitu berupa penambahan nilai di akhir pembelajaran. Namun sampai akhir pertemuan, siwa yang aktif hanya beberapa orang sedangkan yang lainnya masih pasif.

\section{Kesimpulan}

Berdasarkan hasil penelitian dan pembahasan dapat diperoleh kesimpulan sebagai berikut:

1. Model pembelajaran MMP efektif terhadap kemampuan komunikasi matematis siswa kelas VIII A SMP IT Nurul Muhajirin Batam.

2. Model pembelajaran konvensional tidak efektif terhadap kemampuan komunikasi matematis siswa kelas VIII B SMP IT Nurul Muhajirin Batam.

3. Terdapat perbedaan keefektifan model pembelajaran MMP dan model pembelajaran konvensional terhadap kemampuan komunikasi matematis siswa kelas VIII SMP IT Nurul Muhajirin Batam.

\section{Daftar Pustaka}

Ansori, Hidayah \& Aulia, I. (2015). Penerapan Model Pembelajaran Missouri Mathematics Project terhadap Kemampuan Pemecahan Masalah Siswa di SMP. EDU-MAT Jurnal Pendidikan Matematika, 3(1), 49-58.

Giawa, I.R.F, Hutagaol, K \& Saragih, H. (2013). Penggunaan Model Pembelajaran Auditory Intellectually Repetition ( AIR ) untuk Meningkatkan Kemampuan Komunikasi ... In Prosiding Seminar Kontribusi Fisika 2013 (SKF 2013) (pp. 175-180).

Lestari, K. E., \& Yudhanegara, M. R. (2015). Penelitian Pendidikan Matematika. Bandung: Refika Adhitama.

Noviyanti, S., Kartono, \& S. (2014). Penerapan Pembelajaran Missouri Mathematics Project pada Pencapaian Kemampuan Komunikasi Lisan Matematis Siswa Kelas VIII. Jurnal Kreano, 5(September), 212-218.

Rahmi, A., \& Rahmi, D. (2015). Pengaruh Penerapan Model Missouri Mathematics Project terhadap Kemampuan Komunikasi Matematika Siswa SMK Dwi Sejahtera Pekanbaru. Suska Journal of Mathematics Education, 11(11), 28-34.

Ramdani, Y. (2012). PENGEMBANGAN INSTRUMEN DAN BAHAN AJAR UNTUK MENINGKATKAN KEMAMPUAN KOMUNIKASI, PENALARAN, DAN KONEKSI MATEMATIS DALAM KONSEP INTEGRAL Oleh: Yani Ramdani. Jurnal Penelitian Pendidikan, 13(1), 44-52.

Ramellan P, Musdi, E. \& A. (2012). Kemampuan Komunikasi Matematis dan Pembelajaran Interaktif. Jurnal Pendidikan Matematika, 1(1), 77-82. 